Renata CZEKALSKA

Uniwersytet Jagielloński

r.czekalska@uj.edu.pl

\title{
IDEA WOLNOŚCI I EKSPRESJA ARTYSTYCZNEGO BUNTU W NOWOCZESNEJ POEZJI HINDI ${ }^{1}$
}

ABSTRACT The idea of freedom and the expression of artistic protest in modern Hindi poetry

Artistic expression of the idea of freedom in Hindi poetry of the first half of the $20^{\text {th }}$ century evolved from a desire for political autonomy, through a need for social emancipation, towards a desire for freedom of artistic imagination. Since the notions of freedom and artistic individuality - understood in the European manner - did not exist in India, a demand for creative freedom meant not only breaking the accepted aesthetic and artistic rules through introducing a new style or the spoken idiom, but also by rejecting the world-view, determined by the religious and philosophical tradition. This article presents some of the consequences of a distinctive artistic revolt, which on the philosophical level meant simply a desire for the signified to become one with the signifier, and on the strictly literary level - a desire for transgression beyond stereotypes (such as aesthetic cannon, style, etc.), towards the modern form of poetry existing in language.

Słowa kluczowe: nowoczesna poezja hindi, idea buntu, idea wolności, społeczna funkcja poezji, wyobraźnia wyzwolona

Key-words: modern poetry in Hindi, idea of protest, idea of freedom, social function of poetry, free imagination

W całym tekście stosuję spolszczony, fonetyczny zapis indyjskich nazwisk i nazw. Oryginalne tytuły utworów podaję w przypisach, stosując powszechnie przyjęte zasady transliteracji naukowej. Zapis wyrazów indyjskich w cytatach pozostawiam niezmieniony. 
Pisarze i artyści sa najbardziej uwrażliwieni na relacje państwo-twórca. [...] wolność pisarza zawsze będzie nieomylnq wskazówką rzeczywistej wolnościpaństwa².

\section{WPROWADZENIE}

W literaturze indyjskiej powstającej w języku hindi idea wolności, przejawiająca się początkowo poprzez ideę artystycznego buntu, pojawiła się na początku XX w., a rozwinęła w okresie nazywanym przez historyków literatury romantyzmem indyjskim $(\text { ćhajawad })^{3}$, datowanym najczęściej pomiędzy 1918 a 1940 r. Kontynuowali ją później twórcy tzw. nurtu eksperymentalnego (prajogwad) lub szerzej - nurtu nowej poezji (nai kawita) ${ }^{4}$. W artykule ograniczam się wyłącznie do przykładów tekstów powstałych przed 1947 r., czyli przed odzyskaniem przez Indie niepodległości.

W pierwszej części szkicowo przedstawiam ideę buntu w poezji hindi. W części drugiej - ideę wolności politycznej, tak jak daje się ona odczytać z wierszy napisanych przez prekursorów poezji w dialekcie hindi noszącym nazwę khariboli, uznawanym wcześniej za medium stosowne wyłącznie dla mowy potocznej oraz prozy ${ }^{5}$. W analizie ukazuję takie przykłady obrazów poetyckich, których siła ekspresji literackiej ewokuje sensy przekraczające retoryczne zakresy pojęcia wolności. W części trzeciej - rozpatruję zagadnienia związane $\mathrm{z}$ wolnością w dwojakim znaczeniu: $\mathrm{z}$ jednej strony pojmowaną jako absorpcja świata zewnętrznego poprzez własną psychiczność i własną

2 R. Sahaj, Wolność pisarza i wolność państwa, przeł. B. Budzianowska, „Literatura na Świecie” 1980, nr 10, s. 23.

3 Przełom literacki, który dokonał się w poezji hindi w głównej mierze za sprawą czworga twórców: Dźajaśankara Prasada, Sumitranandana Panta, Surjakanta Tripathiego „Nirali” oraz Mahadewi Warmy. Nazwa ćhajawad pochodzi od słowa ćhaja - czyli 'cień, ciemność, niejasność, odbicie', z dodanym przyrostkiem -vad czyli '-izm'. Mimo swego pierwotnie pejoratywnego znaczenia nadana epoce przez krytyków nazwa ćhajawad została szybko zaakceptowana przez opinię publiczną w znaczeniu pozytywnym i uznana za paralelną do angielskiego terminu "romantyzm”, doprecyzowywanego przymiotnikiem ,indyjski”.

4 Do dzisiaj trwa pomiędzy historykami literatury indyjskiej dyskusja dotycząca właściwego sposobu klasyfikowania powstających wówczas nurtów poetyckich. Rodzący się nurt początkowo nazwano pejoratywnie prajogwadem (dosł. eksperymentalizm), co było ewidentnym nieporozumieniem, spowodowanym użyciem przez Agieję we wstępie do pierwszej antologii nurtu - Tàr Saptak - wyrazu prajog (eksperyment) na określenie sfery działalności artystycznej wspólnej dla wszystkich poetów antologii. Dopiero dwie następne antologie - Düsrā Saptak (1953) i Tìsrā Saptak (1959) - zmieniły tę pierwotnie negatywną opinię. Z prajogwadu wyrosła nowa poezja (nai kawita). Z czasem termin nai kawita (w większej części piśmiennictwa historycznoliterackiego) wchłonął niezbyt udaną, pierwotną denominację. Nurt nai kawita trwa w poezji hindi do dzisiaj.

5 Khariboli - dialekt używany m.in. w okolicach Delhi, który odegrał najważniejszą rolę w historii rozwoju standardowego języka hindi, stanowiąc jego bezpośrednią podstawę. Do początku lat 20. XX w. uważano, że dialekt ten nie jest wystarczająco rozwinięty i na tyle melodyjny, aby mógł „udźwignąć” poezję, która wciąż powstawała w akceptowanym przez tradycję literacką hindi dialekcie bradź bhasza, uznawanym za „słodko brzmiący”, a tym samym odpowiedni dla tekstów poetyckich. 
wyobraźnię twórców, z drugiej - jako eksploatacja świata wewnętrznego, uwikłanego w przestrzenie podświadomości i samoświadomości emocjonalnej. Przytoczenia w tej części tekstu przedstawiają sytuacje poetów, którzy eksponując swój nieskrępowany konwencjami indywidualizm, rozumieli go jako niezbywalną część ogólnej wolności, należnej każdej osobie. Część czwartą poświęcam skrótowemu przedstawieniu (również na wybranych przykładach) historyczno-literackich doświadczeń poetów wczesnej fazy (prajogwad) nurtu nowej poezji (nai kawita), którzy z ogromną wrażliwością odczuwali świat i jego problemy, dostrzegając konieczność dokonania zmian w jego funkcjonowaniu.

\section{IDEA BUNTU W POEZJI HINDI}

Zakres semantyczny wyrazu bunt zawiera w sobie dwa krańcowe znaczenia: pierwsze - umotywowany wewnętrznie (psychologicznie, intelektualnie) sprzeciw wobec świata zastanego; drugie - nakaz czynnego przeciwstawienia się światu, który ten sprzeciw wzbudzit. W takim polu znaczeniowym będę rozpatrywać podstawowe aspekty artystycznego buntu, który pozostawił w literaturze hindi swoje ślady, zarówno deklaratywne, jak i przetworzone artystycznie.

Idę̨ buntu w kontekście poezji hindi można rozpatrywać w trzech zasadniczych aspektach. Aspekt pierwszy stanowi poetycką kontynuację idei niepodległości politycznej, realizowanej w praktyce w działaniach podejmowanych przeciwko brytyjskim kolonizatorom. Aspekt drugi - to kwestie nowatorstwa i nowoczesności sztuki. Nowatorzy obalali tradycyjne kanony formalne obowiązujące w indyjskiej literaturze ${ }^{6}$, wybierając dla swoich utworów język potoczny - dialekt khariboli, jak również wprowadzając do tekstów cechy nowoczesności, takie jak wolny dobór tematów, nieskrępowana wyobraźnia czy indywidualizm. W ten sposób nie tylko kreowali własne miejsce w historii literatury indyjskiej, ale i stwarzali sobie sytuację egzystencjalną odmienną od tej, w jakiej działali ich poprzednicy. Aspekt trzeci - będący naturalną konsekwencją dwóch poprzednich - wiąże się z faktem, że poeci nowatorskich nurtów poezji hindi odkrywali własne indywidualności oraz eksplorowali rozległe obszary najważniejszych zagadnień humanistyczno-filozoficznych, takich jak np. problem kolonializmu, spo-

$6 \quad$ Przede wszystkim kanony wypracowane w okresie bezpośrednio poprzedzającym nowoczesne nurty poezji hindi przez kontynuujących wzorce poezji sanskryckiej twórców tzw. epoki kunsztownego stylu (riti), którzy prześcigali się w niezliczonych ozdobnikach stosowanych jako środki wyrazu artystycznego. Jednakże spełnianie ogromnej ilości wymogów formalnych znacznie ograniczyło możliwości indywidualnej ekspresji oraz twórczej inwencji. Nastąpił w rezultacie przerost formy nad treścią. W Polsce o epoce riti pisała m.in. wybitna badaczka tego okresu Tatiana Rutkowska. Poświęciła temu zagadnieniu zarówno pojedyncze artykuły, jak i obszerny rozdział w podręczniku akademickim (Zarys historii literatury hindi, Warszawa 1992). Por. m.in.: taż, Kanon a wartość dzieta literackiego (w obronie literatury riti), „Przegląd Orientalistyczny” 1979, nr 1; taż, Historical Elements in the Riti Poetry (On the Example of Bhušn's Works), [w:] Proceedings of the Fourth International Conference on the Theoretical Problems of Asian and African Literatures, red. M. Gálik, Bratislava 1983. 
sób funkcjonowania tradycji narodowych, kwestie pojmowania religijności, wolności, estetyki ${ }^{7}$ Za historyczno-społeczny paradoks można zatem uznać fakt, że pojawienie się idei wolności w poezji hindi, a tym samym również idei buntu pojmowanego jako pierwszy i konieczny etap dążenia do wolności, stanowi niejako uboczny skutek brytyjskiego kolonializmu. To bowiem dzięki brytyjskiemu systemowi kształcenia przedstawiciele inteligencji indyjskiej uzyskali dostęp do zachodniej myśli filozoficznej i społecznej. Zatem najwcześniejsze przejawy buntu przeciwko zniewoleniu politycznemu miały swoją genezę w wiedzy zdobywanej w wyniku owego zniewolenia. Na marginesie należy w tym miejscu dodać, że paradoks ten miał swoje odzwierciedlenie także w sferze polityki - język angielski był bowiem jedynym medium, które umożliwiało porozumienie działaczom ruchu niepodległościowego pochodzącym z różnych części Indii. Walka o niepodległość toczyła się więc w języku kolonizatorów, który tym samym stał się językiem indyjskiego ruchu oporu.

Logika poetyckiego czy, ogólnie, literackiego przewrotu miała niewątpliwie praktyczne konsekwencje. Na poziomie filozoficznym daje się zauważyć dążenie, aby to, co znaczone, i to, czym jest znaczenie wytworzone przez słowo, stanowiły jedność. $\mathrm{Na}$ poziomie ściśle literackim, w praktyce pisarskiej wskazać można przekraczanie granic w transgresyjnym ruchu pokonywania stereotypów (kanonu estetycznego, stylu etc.) i wyjścia w kierunku nowoczesnych form istnienia poezji w języku. Terminologicznie skalę takich przemian można określić dwoma skrajnymi pojęciami: modus i akomodacja. W polu znaczeniowym pierwszego znalazły się wszystkie sposoby użycia języka oraz sposoby uprawiania autorefleksji. Modulacje tych sposobów, w każdym przypadku autorskim inne, tworzyły jednak pewną wartość wspólnotową. Natomiast akomodacja dotyczyła kwestii obejmujących splot zależności pomiędzy autorem, językiem a percepcją odbiorcy tekstu.

\section{WOLNOŚCIOWE MARZENIA PREKURSORÓW}

Na początku dziejów poezji pisanej w khariboli hindi ${ }^{8}$ jej tematykę zdominowały dwie zasadnicze kwestie. Pierwszą z nich był postulowany kształt przyszłej niepodległości, drugą - problem pojmowania człowieczeństwa. Pomiędzy ostatnią dekadą XIX a pierwszymi dziesięcioleciami XX w. obydwa te zagadnienia - jedno o charakterze politycznym, drugie o charakterze antropologiczno-społecznym - uzyskały artystyczne

W opinii Raghuwira Sahaja, nowoczesnego indyjskiego poety, hindi to [...] jedyny jezzy, z którego bunt ów mógt czerpać potrzebną sitę, a wiadomo, że sita ta ptynęta nie tyle ze związków hindi z sanskrytem, ile z faktu, iż korzenie hindi tkwia $w$ dialekcie apabhranśa, który nastąpitpo sanskrycie w wyniku ostrej reakcji przeciw niemu - R. Sahaj, Wolność pisarza i wolność państwa, przeł. B. Budzianowska, „Literatura na Świecie” 1980, nr 10, s. 8. Podobnie twierdził Alok Rai, pisząc: Jak daleko tylko sięga ludzka pamięć, jezyk hindi zawsze trwat w stanie wojny - A. Rai, Hindi Nationalism, New Delhi 2007, s. 8, Tracts for the Times, 13.

8 Więcej na ten temat zob. m.in.: R. Czekalska, Rodowody nowoczesnejpoezji hindi (od ćhajawadu do nai kawita), Kraków 2008, s. 17-19. 
odwzorowania w wierszach trzech poetów, którzy pierwsi w Indiach wybrali khariboli jako narzędzie literackiej ekspresji. Owi trzej poeci to Śridhar Pathak9 , Ajodhjasingh Upadhjaj ${ }^{10}$ oraz Maithiliśaran Gupta ${ }^{11}$.

Śridhar Pathak był lirykiem pejzażystą, ale i poetą głoszącym pochwałę życia w Indiach oraz pochwałę niepodległości Indii. W swoich wierszach łączył patriotyczną tonację (por. m.in. Pieśń Ojczyzny ${ }^{12}$, Tylko wtasna ojczyzna ${ }^{13}$ ) z kulturowym kontekstem, pogłębiając swoje utwory poprzez związanie asocjacjami treści agitacyjnych $\mathrm{z}$ indyjską tradycją literacko-filozoficzną. Pathak również, w sposób prototypowy dla poezji hindi, ujawnił jeden z ważniejszych problemów XX w. - kwestię obrony własnej tożsamości oraz związany z nią bezpośrednio problem wyznaczania granic wielokulturowości, a zatem problem wolności wyboru ${ }^{14}$. W wierszu $W_{\text {spomnienie }}{ }^{15}$ pisał:

\section{Godny chwaty ten kraj, gdzie szacunek dla swego Uwiktany w pęta, uwięziony w kotowrocie niewiedzy}

9 Śridhar Pathak (1859-1829) swój pierwszy utwór w khariboli, pt. Ekant vasi yogi (Pustelnik), opublikował w 1887 r. Oprócz liryki pejzażowej i patriotycznej uprawiał również poezję o tematyce społecznej, a nawet reformatorskiej.

10 Ajodhjasingh Upadhjaj (1865-1941, używał pseudonimu „Hariaudh”) w 1914 r. opublikował poemat Priyapravas (Podróż ukochanego), napisany w khariboli. Wcześniejsze publikacje ogłaszał w bradź bhasza.

11 Maithiliśaran Gupta (1886-1964) - wybitny poeta hindi, popularnie zwany rasztrakawi (dosł. poeta narodowy). Podczas sześćdziesięciu lat pracy twórczej opublikował około pięćdziesięciu utworów. Gupta był uczestnikiem ruchu narodowowyzwoleńczego w czasach biernego oporu Indusów przeciw Wielkiej Brytanii, a po odzyskaniu niepodległości zasiadał w Izbie Wyższej (Radźja Sabha) indyjskiego parlamentu.

12 Ś. Pāṭhak, Deś gìt, [w:] Kavitā kā śuklpakṣ, red. B. Sim̉h, A. Pradhān, Nayī Dillī 2001, s. 272.

13 Tenże, Nij svadeś hì, [w:] Kavitā kā śuklpaks, s. 273.

14 Przede wszystkim chodzi tutaj o ważny dla tradycji europejskiej, a w początkach XX w. dopiero zarysowujący się w Indiach problem tzw. wolności psychologicznej, przejawiającej się w zdolności człowieka do wybierania jednej lub kilku spośród wielu życiowych możliwości. Kwestia tego wymiaru wolności wiąże się bezpośrednio z nieistniejącym w myśli indyjskiej pojęciem indywidualizmu, a także (co sprzeczne z zasadą karmana) z koniecznością posiadania wiedzy o tym, że istnieją różne możliwości wyboru zależne od woli człowieka, oraz ze zdolnością do oceny wartości podejmowanych wyborów. Osiągnięcie stanu wolności psychologicznej potwierdza się m.in. poprzez umiejętność podjęcia decyzji, dzięki której wola skłania się ku jednej z przedstawionych możliwości i przyjmuje ją w wolnym akcie. Wbrew istniejącej w tradycji indyjskiej deterministycznej zasadzie karmana osiągnięcie takiej wolności jest możliwe, pomimo że człowiek jest w ogromnym stopniu uwarunkowany, m.in. przez dziedziczność czy kulturę. Śridhar Pathak tworzył w czasie, kiedy kwestia podejmowania wyborów stawała się stopniowo koniecznym etapem drogi artystycznego rozwoju. Wybór dialektu khariboli jako narzędzia adekwatnego do tworzywa poetyckiego uważany był za decyzję symbolizującą wyzwolenie się od poetyckiej tradycji wieków poprzednich, a tym samym - w sensie metaforycznym - także od narzuconych przez tradycję reguł funkcjonowania w społeczeństwie kolektywistycznym. Podobnie traktowano podejmowanie w poezji tematów z dziedziny życia społecznego czy politycznego, których obecność w utworach poetyckich uważano za pogwałcenie reguł estetycznych. Warto również w tym miejscu zaznaczyć, że w wielojęzykowej, wieloreligijnej i wielokulturowej rzeczywistości indyjskiej wszelkie artystyczne autodefinicje wymagały (i wciąż wymagają) szczególnej odwagi cywilnej. 
Godny potepienia ten kraj, gdzie swego nie znaja

A szanuja to tylko, co obce i cudze ${ }^{16}$.

Kontekstem dla tego rozróżnienia na kraj „godny chwały” i „godny potępienia” był oczywiście brytyjski kolonializm oraz paradoksy związane z konsekwencjami panowania brytyjskiego w Indiach. Pathak uwypuklił tylko najważniejsze aspekty: kraj „uwikłany w pęta” polityczno-gospodarcze oraz uwięziony w „kołowrocie niewiedzy”. Wymiar owej niewiedzy przedstawił w wierszu Wiedza o ojczyźnie ${ }^{17}$ :

Dopóki każdy z was nie pozna swego

Dopóty nie poczuje, co to mitość ojczyzny

Dopóki ojczyzny drogiej nie uzna za wtasna,

Dopóty nie pojmie, jak mocno jego los z jej losem zwiąany

$[\ldots]$

Póki wtasnego ciata, ducha, majątku, losu, każdego tchnienia z losem kraju nie zwiążesz, Póki jedynej tej wiedzy, która szczęście daje, nie będziesz gtosit

Póty każdy kraj możesz nazwać ojczyzna.

Dwa pierwsze, trochę diaforyczne dwuwiersze zawarte pomiędzy słowami dopóki, dopóty odsyłają do podwójnego doświadczenia trwającego w czasie, do empirycznego poznawania własnej tożsamości (w tym m.in. godności) i do sfery doznań psychicznych związanych z odczuwaniem świata. W przestrzeni tych czterech wersów mieścił się również implicite problem wyobraźni - problem „każdego”. Użycie zaimka „każdy” odnosiło się do wspólistnienia wszystkich we wspólnocie (kastowej, religijnej etc.). Przekonywanie potencjalnych czytelników o konieczności osiągnięcia wiedzy wynikającej z osobistego procesu doświadczeń, zamkniętego w hipotetycznym (dopóki-dopóty) przedziale czasu, było w istocie propozycją nie tylko kształtowania świadomej przynależności do „własnej ojczyzny”, ale również zdobycia świadomości głębszej i wyższej, czyli jedynej tej wiedzy, która szczęście daje. Był to zatem postulat osobowości integralnej i pewnej swojej tożsamości, osobowości wyzwolonej.

Dramatycznym przeciwieństwem takiego stanu świadomości była perspektywa duchowej bezdomności, którą poeta wypowiada drwiącym zdaniem: każdy kraj możesz nazwaí ojczyzna.

Drugi z poetów, Ajodhjasingh Upadhjaj „Hariaudh”, problematyce duchowej i egzystencjalnej wolności poświęcił m.in. wiersz Kropla ${ }^{18}$. Wyeksponował w nim podstawowe i powszechne w różnych epokach i środowiskach doświadczenie wydziedziczenia

16 Jeśli nie zaznaczono inaczej, wszystkie cytowane w artykule fragmenty wierszy zamieszczam w przekładzie własnym (z języka hindi).

17 Ś. Pāthak, Svadeś-vijñyan, [w:] Kavitā kā śuklpakș, s. 274.

18 A.S. Upādhyāy, Ek būind, [w:] Kavitā kà suklpaks, s. 283. 
i przemiany. Wydziedziczenie ukazał na przykładzie utraty domu, a przemianę porównał do narodzin perty:

Ach! Czemuż dom mój przyszto mi porzucić?

Cóż to chciat bóg wyrazić losem mnie pisanym [...]

$[\ldots]$

Otwarte trwaty usta pięknej muszli

Kropla w nie wpadta i stata sięperta.

$[\ldots]$

Zwykle się cztowiek zagubiony smuci,

Gdy mu dom wtasny opuścić przychodzi,

A przecież często gdy już dom porzuci,

Niczym ta kropla kimś innym się rodzi.

W tekście nie ma wyjaśnienia przyczyn porzucenia domu, a wykrzyknik „ach!” ukazuje - czy też jedynie sugeruje - sferę emocjonalnych doznań, natomiast kwestię przyczyn przenosi do ogólnie pojętego „losu”, którym kieruje anonimowy „bóg”. Jest jednak w pierwszych dwóch linijkach wiersza wyraźnie słyszalny ton melancholijny, jakieś pogodne poddanie się losowi, rozumianemu tutaj jako przeznaczenie. Przeznaczenie objawia się poecie jako wyraz woli wyższej, transcendentnej, boskiej. Takie dwustopniowe ujęcie bytowania człowieka na ziemi ukazuje przestrzeń pomiędzy przeznaczeniem, niezależnym od jego decyzji i działań, a potrzebą wewnętrznej przemiany, wynikającą $\mathrm{z}$ konieczności przystosowania się. Ta przestrzeń jest właśnie przestrzenią indywidualnego doświadczenia życia. Wyraża ją sugestywny obraz „otwartych ust muszli”.

Zanim poddam ten obraz interpretacyjnemu odczytaniu jego znaczeń, zwracam uwagę na dwustopniowy porządek toposów, będący odwzorowaniem całej konstrukcji wiersza. Na stopniu pierwszym znajdują się: dom, usta, muszla, kropla, perła, na stopniu drugim: samotny, nieznany bóg - czyli odpowiednio: ziemia i transcendencja. Topika przyjętego porządku charakteryzuje i równocześnie metaforyzuje los poety-człowieka. Poetyka wypowiada egzystencję. Dom oznacza miejsce życia osobistego, schronienie, ale równocześnie ewokuje wszystkie strefy psychologicznych uwarunkowań związanych z codziennością, od genetycznych, rodzinnych po społeczne czy językowe, od kulturowych po religijne. Jest więc toposem archetypicznym. Podobnie jest z toposem ust, związanym z ekspresją mowy, zarówno tej wyrażanej słowami, jak i mimiką, kształtem warg, ich ruchem, ułożeniem etc. Ale usta kojarzą się także z twarzą, epifanią twarzy. Metafora ust użyta w tym wierszu oznacza „poszanowanie bytu” ${ }^{\text {, }}$ w tym przypadku człowieczego, lecz również każdego głosu, każdego życia.

Także muszla wyraża, jako obraz, coś znacznie więcej aniżeli tylko zewnętrzny szkielet wapienno-konchiolinowy mięczaka - tutaj może np. oznaczać formę losu. Bo choć proces powstawania muszli jest różny u różnych gatunków, jednak wszystkie związa-

19 E. Lévinas, Catosśc i nieskończoność. Esej o zewnętrzności, przeł. M. Kowalska, Warszawa 1998, s. 59, Biblioteka Wspótczesnych Filozofów. 
ne z nim skojarzenia podpowiadają wysiłek, pracę, trud, cierpienie. Jeżeli dodamy do tych skojarzeń szum, jaki daje się słyszeć wewnątrz muszli morskiej - wtedy obraz ten ewokuje nie tylko formę losu poety, jakby słyszanego w obrazie muszli, ale także jego głos wewnętrzny, wydobywający się z wnętrza tego słowa-obrazu, oraz inne głosy świata minionego.

Głównym obrazem wiersza jest z całą pewnością „kropla wpadająca w usta muszli”. Chociaż samego momentu spadania kropli poeta nie pokazuje, to jednak podpowiada pewien moment otwarcia, wystarczająco długi, aby samo zdarzenie mogło zaistnieć („usta trwały”). Trwanie w otwarciu jest stanem zaproszenia, możliwości, potencjalności. Toteż informacja: kropla w nie wpadta $i$ stata sięperta, streszcza po prostu ewolucję kropli, aż do stanu skupienia w perłową masę. Jedynie zdanie kropla w nie wpadta zawiera aluzję do niespodziewanej dramatyczności zdarzenia. W wierszu nacechowanym dydaktyzmem, a takim jest Kropla, opis samego mikroprocesu przemiany zakłóciłby tok wywodu, zmierzającego do konkluzji. Pominięcie opisu bólu i cierpień towarzyszących powstawaniu perły (a zatem również brak bezpośredniego odwołania do powszechnie powtarzanej prawdy, że osiągnięcie w życiu tego, co prawdziwie wartościowe, wymaga poświęceń, cierpień i wyrzeczeń, ale przynosi zwykle spektakularny efekt) powoduje, że dydaktyczne przesłanie wiersza nabiera subtelności. Można jednak zasadnie przyjąć, że autor świadomy jest wszystkich ewokowanych przez metaforę powstawania perly odniesień do kompleksowego kontekstu tradycji, czyli tego, co współcześnie nazywamy kodem kulturowym.

Kropla jako zjawisko fizyczne to mała ilość płynu w kształcie kulistym, ale przy spadaniu przemienia się w kształt wydłużony, jak np. krople deszczu. W Atharwawedzie [w] da uważana jest za prawdziwa "wodę życia", jak czytamy w hymnie 1.6. - Do Wody. Woda skrywa w sobie wielka moc - moc wszystkich leczniczych roślin, gdyż bez niej wszystko martwieje $e^{20}$. Chronologicznie późniejsze dzieło, Bhawiszjottarapurana, zawiera zawołanie: Wodo, ty jesteś źródtem każdej rzeczy i wszelkiego istnienia!?2. O tym zawołaniu orzekł Eliade, że streszcza w jednym zdaniu dtugoletnia tradycje wedyjską $q^{22}$. Wniosek, jaki czytelnik współczesny wyprowadza z tego tekstu Upadhjaja sprzed ponad stulecia, jest taki, że wiersz pozostaje „zanurzony” głęboko w tradycyjnej symbolice indyjskiej.

Dopiero w tych symbolicznych asocjacjach odczytywać należy miejsce i znaczenie perły w owym wierszu. Jest to miejsce przeistoczenia się w cierpieniu, przekształcenia starego w nowe. Usta pięknej muszli - to statyczny obraz świata materialnego, obraz ziemi w kosmosie wszechświata. Kropla symbolizująca życie, wpadając do muszli, sprawia, że zaczyna koncentrować się wokół niej substancja szlachetna, nazywana półperłą, i dopiero wchłaniając inne komórki substancjonalnego życia, uzyskuje kształt i barwę perły pełnej - symbolu piękna. Na okoliczność odczytania zasadniczego przesłania tej metafory nie ma potrzeby szczegółowego odtwarzania procesu rodzenia się perły.

20 Por.: H. Marlewicz, Atharwaweda - wiedza zapomniana, [w:] Atharwaweda. Hymny wybrane, przeł. H. Marlewicz, C. Galewicz, Kraków 1999, s. 5.

21 Cyt. za: M. Eliade, Traktat o historii religii, przeł. J. Wiertusz-Kowalski, Łódź 1993, s. 185, Plejada.

22 Tamże. 
Konieczne jest tylko zaznaczenie jego elementów: drogi, cierpienia, sensu. Taki symbol, jak perta - pisał Eliade - usituje wyrazić jednocześnie dwa systemy symboliczne (księżca $i$ wód), wcielając w sobie niemal wszystkie epifanie życia ${ }^{23}$.

W metaforycznym obrazie „kropli wpadającej w otwarte usta muszli”, a zatem unikając dosłowności opisu cierpień towarzyszących każdej istotnej przemianie (w sposób naturalny wywołujących wszak sprzeciw bytu cierpiącego, a przynoszących w rezultacie poczucie wyzwolenia towarzyszące osiągnięciu celu), Upadhjaj ukazał symboliczny sens ludzkiego losu - sens w wymiarze uniwersalnym.

Trzeci z trójki prekursorów, Maithiliśaran Gupta, problemowi niepodległości Indii, jak i problematyce człowieczeństwa w Indiach kolonialnych poświęcił w swojej poezji tyle miejsca, że uznany został za pierwszego indyjskiego poetę narodowego. Jeden z jego wierszy, zatytułowany Cztowieczeństwo ${ }^{24}$, łączył w sobie tę podwójną tematykę. Przytoczę najważniejsze fragmenty:

Wyobraź sobie, że żyjesz i nigdy nie boisz sięśmierci,

Umierasz, jednak wówczas pamiętaj, że wszystkich to czeka

$[\ldots]$

Trzeba wspótczucia, to wielka sita;

Ojczyzna, choć zniewolona, wtasna stworzyta potege

Czas buntu, taska mądrości ptynie strumieniem,

Świat prawy, czy nie pochylimy przed nim gtów?

Tak! Ten jest szlachetny, który dziata dla innych,

Ten jest cztowiekiem, który umrzeć gotów za cztowieka.

[...]

Chodźmy wymarzona drogą, bawmy się i weselmy,

Nieszczęścia, niepokoje pokonujmy, kiedy nadejda.

Pomimo retorycznego stylu i patosu wiersz ten był w zasadzie programową wizją życia dla siebie i wspólnoty. Dwa kategoryczne nakazy zwracają szczególną uwagę: wyobraź sobie, że żyjesz i chodźmy wymarzona drogą. Wyobraźnia i marzenie należą do tych wartości, które konstytuują duchową wolność człowieka. Mają jedną wspólną cechę zarówno poprzez wyobraźnię, jak i poprzez marzenie człowiek może zobaczyć rzeczywistość potencjalną, możliwą nie tylko w przyszłości, ale teraz, w czasie teraźniejszym.

Wyobraź sobie, że żyjesz - to wspaniała projekcja dystansu, spojrzenia na własną egzystencję jakby z boku albo z góry, projekcja duchowej wolności bez lęku przed śmiercią. Uzyskanie stanu wolności duchowej w marzeniu i wyobraźni wynosi egzystencję człowieka ponad doczesność, w strefę suwerennej godności wyboru. W takim kontekście uznanie za szlachetnego kogoś, kto żyje dla innych, kto gotów jest umrzeć za drugiego człowieka, zyskuje najwyższą sankcję etyczną: wpisanie w bohaterstwo. A zrów-

Tamże, s. 434.

24 M. Gupt, Manusyatā, [w:] Maithilīśaran Gupt. Samicayitā, red. N. Naval, Naī Dillī-Paṭnā 2002, s. 174 . 
nanie czasu buntu z laską mądrości, która ptynie strumieniem (co sugeruje przecież tzw. strumień życia), jest ekstrapolacją pochwały życia poświęconego prawości („prawemu światu”), przed jakim pochylają głowy ci, którzy współczują, którzy pragną prawości. Pragnienie w tym wierszu jest tożsame z wyobraźnią i z marzeniem, poetycki program wyrażony przez autora jest zaprzeczeniem martyrologicznego rozumienia patriotyzmu: chodźmy wymarzona drogą, ale równocześnie bawmy się i weselmy. Chociaż ojczyzna jest zniewolona, to przecież stworzyła własną potęgę, przede wszystkim duchową, ufundowaną na współczuciu - moralnym oparciu szlachetności.

\section{LIRYCZNE TRANSGRESJE POETÓW EPOKI ĆHAJAWADU ${ }^{25}$}

W żywiołowym ruchu literackich indywidualności, jakim w istocie był nurt romantyczny w poezji hindi, czyli ćhajawad, pojęcie wolności odnosiło się przede wszystkim do wolności tworzenia, miało więc sens ściśle artystyczny. Ale samo pojęcie wolności twórczej implikowało również inne znaczenia, od politycznych po metafizyczne, funkcjonujące na różnych poziomach samoświadomości autorskiej.

Ćhajawad narodzit się pod gwiazdą romantycznego, mesjanistycznego patriotyzmu, pisała pierwsza polska badaczka indyjskiej poezji współczesnej, Agnieszka Kowalska$-{ }^{-S o n i}{ }^{26}$. Stanowił więc kontynuację historycznej idei niepodległości politycznej i równocześnie realizację - na poziomie pisarskim - wolności indywidualnych. Nie bez znaczenia była czasowa bliskość z „akcją obywatelskiego nieposłuszeństwa” Gandhiego i oficjalnym ogłoszeniem przez Indyjski Kongres Narodowy zasadniczego celu politycznego - niepodległości Indii. Na tym tle społecznym poezja ćhajawadu, wprowadzając do literatury indyjskiej liryczne „ja”, dokonała gloryfikacji jednostki, afirmacji indywidualnej percepcji świata, a zatem akceptacji cielesności człowieka, a także prawa do indywidualnego pojmowania wyobraźni. To wyzwolenie się od konwencjonalnych form oraz przejście do indywidualnego pojmowania wyobraźni twórczej ${ }^{27}$ dokonało się w różnych poetykach, a ślady tego przejścia pozostały w tekstach. Te ślady to różne

25 Pisząc o transgresyjnym przekraczaniu granic poezji, mam na myśli przede wszystkim definicję transgresji Józefa Kozieleckiego, który stwierdził, że [t] ransgresja polega na przekraczaniu dotychczasowych granic materialnych, spotecznych i symbolicznych, na rozszerzaniu sfery wtasnej dziatalności, na tamaniu tabu, na wychodzeniu poza to, czym jednostka jest i co posiada. Dzięki tym „czynom-wyczonom” rodzi się zmiana spoteczna, rozwija siękultura i cywilizacja - J. Kozielecki, Transgresja i kultura, Warszawa 1997, s. 10.

26 A. Kowalska-Soni, Wspótczesna poezja hindi a rodzima tradycja literacka, „Przegląd Orientalistyczny” 1968, nr 1, s. 29.

27 Wynalazek wolności obywatelskiej (termin Jeana Starobinskiego) w Europie pochodzi z epoki Oświecenia i w nauce łączony jest z początkami pojmowania nowoczesności. Warto też odnotować słowa Józefa Bolesława Ostrowskiego z czasów powstania listopadowego: My pod choragwia romantyczności, burzacej dawne prawidta $w$ sztukach, filozofii, wzywajacej niczym nie ograniczonej wolności myślenia... Cyt. za: Walka romantyków z klasykami, wstęp i oprac. S. Kawyn, Wrocław 1960, s. 390, Biblioteka Narodowa, I 183. Kontekst, mimo czasowej odległości, posiada walor myślowej symetrii. 
sposoby pojmowania i nazywania wolności przez twórców romantycznego nurtu poezji hindi.

Sposób postrzegania rzeczywistości był bowiem u poetów ćhajawadu indywidualny, ale to, co widzieli, stanowiło odkrycie obiektywnie istniejących problemów. Surjakant Tripathi, tworzący pod pseudonimem „Nirala”28, w wierszu Przebudź się znów z 1921 r. napisał:

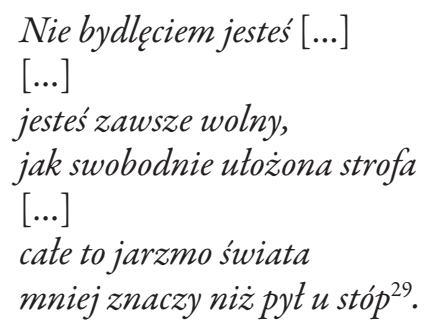

W cytowanym fragmencie nastąpiło utożsamienie wolności i sztuki (człowieka i języka), co pozostawało motywem przewodnim tej liryki. Ale zakres problemów, które poeci ćhajawadu odkrywali, obejmował właściwie pełne spektrum zagadnień społecznych i artystycznych. Żeby jednak te problemy zobaczyć, konieczna była zmiana optyki. Wybór innego sposobu patrzenia na rzeczywistość dotyczył zarówno poetów, jak i - w niemałej mierze - odbiorców (tj. czytającej części społeczeństwa). Poeci ćhajawa$d u$ realizowali bowiem wizję czegoś, co z perspektywy historycznej można określić jako postulat budowania „światoobrazu”, wspólnego im samym oraz czytelnikom.

Problem postrzegania języka jako tworzywa w pierwszej fazie ruchu poróżnił autorów z czytelnikami (i krytykami). Ostateczny - bo historyczny - triumf nad tradycyjną konwencją i powielaniem wzorców odnieśli poeci.

Dla Dźajaśankara Prasada ${ }^{30}$ wolność tworzenia była synonimiczna z pamięcią traktowaną jako jedna z form przezwyciężania mijającego czasu. Z kolei dla Sumitranandana Panta $^{31}$ emanację wolności stanowiła nieskrępowana obserwacja świata realnego, zapi-

28 Surjakant Tripathi „Nirala” (1899-1961) - poeta i prozaik; autor dwudziestu ośmiu książek: piętnastu zbiorów poezji, ośmiu powieści, pięciu zbiorów opowiadań. Nirala eksperymentował z nowymi formami ekspresji i jemu właśnie większość krytyków przypisuje wprowadzenie do poezji hindi wiersza wolnego.

29 Fragment wiersza Przebudź się znów [Jāgo phir ek bār] w przekładzie Agnieszki Kowalskiej-Soni, cyt. za: taż, Wspótczesna poezja hindi a rodzima tradycja literacka, „Przegląd Orientalistyczny” 1968, nr 1 (65), s. 28.

30 Dźajaśankar Prasad (1899-1937) - poeta, prozaik, dramaturg; autor trzydziestu czterech książek: trzynastu zbiorów poezji, pięciu zbiorów opowiadań, trzech powieści, trzynastu dramatów. Prasad był pierwszym z wielkiej czwórki twórców ćhajawadu, który odważył się przedstawić w poezji hindi nowe spojrzenie na rzeczywistość otaczającą człowieka. Już w 1909 r. wyraził opinię, że poezja nie może być ograniczona żadnymi zasadami, ponieważ jest wolną i naturalną ekspresją indywidualnego geniuszu.

31 Sumitranandan Pant (1900-1977) - poeta i prozaik; autor trzydziestu czterech książek: trzydziestu dwóch tomów poezji i dwóch zbiorów opowiadań. Jego wczesna twórczość wzorowana była na poezji Rabindranatha Thakura (Tagore), Dźajaśankara Prasada oraz Maithiliśarana Gupty. Przyroda i jej 
sywana poprzez transmutacje obrazów rzeczywistych w struktury języka. Jednak najciekawsze w poetyckim kwartecie ćhajawadu wydają się dwa zupełnie odmienne - zarówno od powyżej przedstawionych, jak i od siebie nawzajem - sposoby artystycznego podejścia do problematyki wolności ${ }^{32}$. Pierwszy reprezentowany przez „Niralę”, drugi - przez Mahadewi Warmę $e^{33}$.

Surjakant Tripathi „Nirala” pojmował swoją misję niemalże na równi z kapłaństwem. Przykłady takiego podejścia można znaleźć w wielu jego tekstach, spośród których wybrałam wiersz To prawda ${ }^{34}$, przedstawiony tutaj w dwóch krótkich fragmentach:

\section{To prawda \\ podarunek od ciebie: \\ dumna stużba jezykowi hindi; \\ mądrości ludowe z pierwszej ręki- \\ to prawdziwe btogostawieństwo. \\ To prawda.}

Zwróćmy uwagę na sąsiedztwo dwóch słów: dumna i stużba. Wyraz dumna przynależy do porządku patetycznego, wyraz stużba - wprost przeciwnie, kojarzony jest $\mathrm{z}$ usługiwaniem, podrzędnością społeczną, statusem pariasa. Zestawione razem - zmieniają swoje denotacje, stają się wyrazem dystynkcji i godności obywatelskiej. Jest w takim ujęciu pisarskiej powinności wyraźny rys szlachetności: dumna stużba językowi. Dwa sensy rozbieżne zostały scalone w jeden sens integralny, racjonalny, mimo że łączący sprzeczności. Można zatem dosłyszeć w takiej frazie dalekie echo kultu poety jako kapłana słowa, echo indyjskiej tradycji kulturowej. Nirala odwołał się więc do funkcji słowa i funkcji kapłana słowa, a dopowiedzeniem tej funkcji, już na płaszczyźnie doświadczenia egzystencjalnego, jest puenta wiersza:

\section{Pokonywany po stokroć}

nowej klęski szukam w popiotach.

Pyt wznióst się i wypetnit ciato.

różnorodne zjawiska były dla poety źródłem inspiracji i natchnienia. Nazywano go „piewcą natury”. Obok form tradycyjnych Pant stosował także zrytmizowany wiersz wolny.

32 W tym miejscu należy zaznaczyć, że zarówno indyjscy czytelnicy, jak i krytycy literaccy zarzucali poetom ćhajawadu brak wystarczającego zainteresowania kwestią dla narodu najistotniejszą, to znaczy problemem walki o niepodległość. Na przykład Raghuwir Sahaj w cytowanym już eseju Wolność pisarza a wolność państwa stwierdzał: Poeci jezyka hindi, należacy do grupy określanej później mianem szkoty ćhajawad, byli pochtonięci poszukiwaniem jaźni przez utożsamienie się z naturą. Niektórzy z wspótczesnych im bardziej zdecydowanie dawali wyraz potrzebie identyfikacji z ruchem wolnościowym, ale oni sami zachowali gtęboko zakorzeniona tęsknotę za kulturalna przesztością Indii - R. Sahaj, Wolnośćpisarza..., s. 7.

33 Mahadewi Warma (1902-1987) - poetka i prozaiczka; autorka dwunastu książek: sześciu zbiorów poezji, pięciu tomów opowiadań, tomu wspomnień. Swoje życie poświęciła pisarstwu, pracy naukowej i działaniu na rzecz wyzwolenia kobiet. Debiutowała wierszami napisanymi w latach 1924-1928, opublikowanymi w 1930 r. w książce Nihar (Mgła). Na początku lat 40. XX w. zaprzestała pisania poezji.

Nirālā, Sac hai, [w:] Nirālā saricayitā, red. Ḍ. Rameścadr Śāh, Nayī Dillī 2001, s. 87. 
Ani jednego paka: życie nie rozkwitto.

To prawda.

Dramatyczna relacja, zawarta w określeniach: pokonywany, klęska, popioty, pyt wypetniajacy ciato - to skondensowana wizja kresu egzystencji, zakończonej rytuałem całopalenia. Mowa, która jest błogosławieństwem, ogniem wewnętrznym, jest jednocześnie ogniem spalającym ciało. Mowa poety - będąca narzędziem sprzeciwu, wolna od wszelkich ograniczeń, trwająca tak długo jak kultura, a może i świat - pozostaje ponad czasem historycznym ${ }^{35}$.

Spośród wierszy Mahadewi Warmy nawiązujących do tematu wolności indywidualnej oraz artystycznej wybrałam taki, w którym poetka najpełniej zaprezentowała swoje egzystencjalne ,ja” i który zatytułowała programowo: Jestem lutnia, jestem twoja melodią ${ }^{36}$. Utwór uznać można za filozoficzną wykładnię poglądów autorki.

Jestem lutnia, jestem twoją melodia!

Miatam sen klarowny w kazdej jego chwili,

pierwsze przebudzenie w pierwszym drżeniu świata,

w potopie mój ślad, odcisk stopy w mym życiu,

jestem klatwa obrócona w btogostawieństwo,

jestem brzegiem, jestem rwacym strumieniem!

Jestem kukutka żadna chmurnych oczu, jestem okrutna lampa, w której tchnieniu ćma, jestem niespokojnym stowikiem w sercu kwiatu, jestem zarówno cieniem, jak i ciatem, daleko od ciebie, lecz jestem szczęśliwa!

Jestem ogniem, który stwarza krysztatki lodu, jestem pustka nakryta dywanem chwil, jestem radościq wzniesiona na twardej skale, jestem zwierciadtem serca, jestem obtokiem, jestem ztota btyskawica!

Jestem zniszczeniem, rozwojem bez kresu, jestem dniem poświęcenia, mrokiem narkotyku, jestem struna, powiewem, wibracją dźwięku, jestem kielichem, miodem, stodkim zapomnieniem, jestem ustami, jestem uśmiechem księżyca.

$35 W$ hindi buntowniczy duch Nirali odrzucit archaiczna idiomatykę wcześniejszych poetów jako zbyt uciązliwa i paralizujaca w czasach emancypacji spotecznej i politycznej. Przez pewien czas byt to jedyny przyktad wielkiego poety, który zerwat trwale $z$ tradycja wiersza rymowanego i metrycznego - R. Sahaj, Wolnośćpisarza..., s. 7.

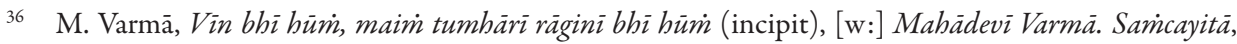
red. N. Jain, Nayī Dillī 2002, s. 52. 
Siedemnaście razy wersy rozpoczynają się od ekstatycznego (niemal na granicy krzyku) stwierdzenia: jestem - a potem następują utożsamienia. Wewnątrz tych siedemnastu wersów w pięciu przypadkach (wersy 1, 6, 11, 16,21) oznajmienie jestem - pojawia się wewnątrz wersu. W każdym z tych pięciu przypadków słowo jestem - dotyczy utożsamienia się ze zjawiskami nie tyle sprzecznymi empirycznie, co uzupełniającymi i łączącymi obraz w całość.

Przestrzeń tekstu obejmuje wielki obszar, który można jedynie zakreślić przy pomocy punktów granicznych. Na horyzoncie tej potężnej wizji pojawiają się: „pierwsze drżenie świata”, moment jego stworzenia oraz „zniszczenie” i „rozwój bez kresu”. Zatem jest to wizja koła przemian. Na obwodzie tego koła znajdują się wszystkie przejawy życia ziemskiego, z którymi poetka tak ekstatycznie się utożsamia. Od pierwszego śladu na wodzie - po uśmiech księżyca. Poszczególne utożsamienia sprawiają wrażenie chaosu, nawet przypadkowości, ale uporządkowane według kryteriów hierarchicznych (tj. ważności symboli), układają się w logiczne ciągi ${ }^{37}$. Poetka utożsamia się np. zarówno z lutnią, jak i z melodią, z przedmiotem oraz wrażeniem akustycznym. Wszak być instrumentem i muzyką to znaczy być przyczyną i skutkiem.

W sensie gatunkowym wiersz jest rodzajem hymnu o wyzwoleniu, o utożsamieniu bytu osobowego „ja” z Bytem Absolutnym, które w tradycji indyjskiej oznacza realizację celu, osiągnięcie stanu niezmąconego spokoju, pełnego wyzwolenia, odkrycie własnej tożsamości z atmanem ${ }^{38}$. Na tym poziomie skojarzeń - od melodii w pierwszym wersie do ust w ostatnim - zamyka się krąg asocjacji prowadzących do konkluzji, że świat ma formę dźwięku czy - jak napisał Rainer Maria Rilke - jest śpiewem wszechrzeczy ${ }^{39}$.

Poezja ćhajawadu była nieuniknioną konsekwencją wewnętrznych procesów historycznych dokonujących się w Indiach w pierwszej połowie XX w.; była obrazem - odbitym w słowach - intelektualnych skutków tych procesów. Dwa radykalne wyznaczniki poezji ćhajawadu - wybór khariboli oraz wybór indywidualnej wolności wyobraźni - były przejawami duchowego buntu. Ten właśnie bunt stał się przyczyną całego zespołu zjawisk przebiegających od pragnienia wolności politycznej (czyli niepodległości państwowej) do pragnienia spełnionej wolności społecznej (czyli emancypacji jednostki). Była to w istocie zmiana reguł w indyjskiej tradycji religijno-filozoficznej i wytworzenie sytuacji, którą z perspektywy filozofii europejskiej można byłoby opisać, używając słów Michaela Foucaulta. Bowiem sprzeciw poetów hindi, zarówno wobec braku wolności politycznej, jak i wobec braku wolności artystycznej, doprowadził do sytuacji, w której - cytując Foucaulta - Podmiot [w tym przypadku poeta - R.C.] przejmuje

37 Taki schemat obrazowania przywołuje skojarzenia z mandalą, którą włoski badacz Giuseppe Tucci zdefiniował następująco: Mandala to $w$ istocie kosmogram, zasadniczy schemat strukturalny catego Wszechświata we wtaściwym mu procesie emanacji i resorpcji - G. Tucci, Mandala, przeł. I. Kania, Kraków 2002, s. 34. atman - pojęcie z dziedziny indyjskiej filozofii o szerokim zakresie znaczeniowym; może oznaczać duszę, tożsamość, jaźń, podmiot transcendentny.

39 Por.: Sonety do Orfeusza, cz. 3, [w:] R.M. Rilke, Śpiew jest istnieniem, przeł. B. Antochewicz, Wrocław 1994. 
miejsce i funkcje spetniana w klasycznych metafizykach przez takie kategorie, jak Logos, Byt i Bóg $g^{40}$. Była to zmiana ekstremalna, dająca poecie, czy raczej poetyckiemu słowu, realną siłę oddziaływania na rzeczywistość.

\section{IDEA WIERSZA WOLNEGO I SPRAWA WYOBRAŹNI ARTYSTY}

Dla siedmiu poetów nowatorów z kręgu antologii Tar Saptak ${ }^{41}$ zasadniczym problemem warsztatowym była kwestia wyboru formy wiersza. Miała ona implikacje światopoglądowe, które ten wybór całkowicie uzasadniały. Skoro poeci ci odrzucali cały świat umocowanych w tradycji indyjskiej społecznych struktur, logicznym następstwem było odrzucenie historycznych form poezji. W literaturze indyjskiej była to wielowiekowa tradycja wiersza regularnego, tradycja obecna w świadomości społeczeństwa, a szczególnie jego warstw uprzywilejowanych i światłych intelektualnie, upowszechniona i uświęcona powszechną akceptacją ze strony poetów i czytelników.

Rozwiązując dylemat pozornie tylko warsztatowy: „odrzucając tradycję - co wybieramy?", wybrali wiersz wolny jako podstawową formę pisarskiej wypowiedzi. Jesteśmy poszukiwaczami, napisał we wstępie do Tar Saptak Agieja ${ }^{42}$, pomysłodawca, redaktor i jeden z siedmiu autorów antologii. Jednakże to odejście od dogmatycznych regul formalnych indyjskiego wiersza powodowało dwa następne problemy: kwestię wyobraźni i kwestię roli artysty w społeczeństwie ${ }^{43}$. Obie te kwestie były dla wszystkich siedmiu

40 Definicja teorii funkcji podmiotu, utożsamianej z antropologią filozoficzną, Michela Foucaulta (w Stowach i rzeczach i Archeologii wiedzy), zreferowana przez Charlesa C. Lemerta i Gartha Gilliana. Zob.: ciż, Michel Foucault. Teoria spoteczna i transgresja, przeł. D. Leszczyński, L. Rasiński, Warszawa-Wroctaw 1999, s. 136.

41 Tãr Saptak (Siedem brzmień wysokich) - antologia nowoczesnej poezji hindi opublikowana w 1943 r. w Delhi. Zamieściło w niej swoje utwory następujących siedmiu autorów (według kolejności w zbiorze): Gadźanan Madhaw Muktibodh, Nemićandr Dźain, Bharatbhuszan Agrawal, Prabhakar Maćwe, Giridźakumar Mathur, Ramwilas Śarma oraz Agieja, który był jednocześnie organizatorem, selekcjonerem tekstów, wydawcą i współautorem antologii.

42 Agieja (1911-1987, właśc. Saććidanad Hiranand Watsjajan) - poeta, prozaik, eseista, tłumacz, redaktor, wydawca. Autor pięćdziesięciu książek: dziewiętnastu tomików poezji, sześciu powieści, siedmiu zbiorów opowiadań, dwóch tomów wspomnień z podróży, dwunastu zbiorów esejów, czterech pamiętników; edytor około dwudziestu książek. Tłumaczył na język hindi m.in. Iwo Andricza, Romaina Rollanda, Rabindranatha Thakura, Pära Lägerkvista.

43 Bezpośrednią zależność, jaka w przypadku literatury indyjskiej powstającej w języku hindi wystąpiła pomiędzy rezygnacją artysty z przestrzegania reguł dogmatycznej poetyki a przewartościowaniem jego roli w społeczeństwie, można w pewnym sensie nazwać nową formą wolności, eufemistycznie określaną czasem wolnością wyobraźni. Taka wolność, polegająca na odnajdywaniu tożsamości, z jednej strony pozwalała leczyć się z ran konwencjonalnego myślenia, z drugiej - stała się symbolem wolności indywidualnej w ogóle. Syntetycznie podsumowuje tę sytuację S.H. Watsjajan "Agieja” (por. przyp. 42), stwierdzając, że literatura powstająca w języku hindi byta zawsze raczej literatura nurtów [czy raczej szkół poetyckich - R.C.] niż dokonań indywidualnych [...]. Dopiero od schytku XIX wieku, od momentu, gdy popularna stata sie zachodnia koncepcja artysty pojmowanego jako jednostka wyjątkowa $i$ wolna, status artysty indywidualnego nabrat istotnego znaczenia. [...] W tradycji, w której epoka zawsze byta ważniejsza od artysty, literatura w oczywisty sposób skupiata się raczej na kreowaniu 
poetów ważne. Jednak najlapidarniej, i jednocześnie poetycko, całą sytuację historyczną i psychologiczną przedstawił Agieja w wierszu Wyzwolony ${ }^{44}$ :

\section{Strażnik mojego serca zasnąt na moment- \\ Wówczas pękta gruba lina ciężkiej ascezy - \\ Strzata prawdy trafita az poza serce -}

Otwierajac wszystkie zakazane bramy fortu wyobraźni!

Stylistyka tego obrazu otwartych bram zakazanego fortu wyobraźni wykazuje dramatyzm wyboru. Wynika z niego, że poeci antologii Tar Saptak - mimo iż należący do wczesnej fazy nurtu nai kawita - mieli już ukształtowaną świadomość własnej postawy ideowej i artystycznej. Poglądami różnili się niekiedy zasadniczo, lecz mimo że każdy z nich miał swoje indywidualne przekonania filozoficzne, łączyła ich nie tyle wspólnota pokoleniowa, ile wspólne przekonanie, że nowe myśli należy wypowiadać nowym językiem i w nowej artystycznie formie. Ich poszukiwanie nie było eksperymentem wyłącznie warsztatowym, lecz łączyło się z nowym pojmowaniem świata i roli poety w świecie. W swojej poezji wypowiadali wiedzę o dramatach współczesnego im człowieka i wyrażali te dramaty w liryce konstruowanej w wersyfikacji wiersza wolnego, eksploatującej niedefiniowalne retorycznie i nieograniczone niczym oprócz niej samej obszary ludzkiej wyobraźni.

Marksizująca krytyczka Helena Zaworska pisała kiedyś o polskich poetach futurystach, że [j]ako apologeci dobrodziejstw nowoczesnej cywilizacji [...] stawili miasto, maszyne, ruch, pośpiech, ttum, racjonalna organizację życia. Ale nie wyrzekali się przy tym tęsknot do przeżyć irracjonalnych, nielogiczności, niespodzianki, instynktu. Chcieli być wyzwoleni od natury, od jej panowania nad cztowiekiem - cywilizacja dawata im te szansę. Ale [...] w pewnym sensie chcieli być również wolni od cywilizacji, od licznych jej skutków ograniczajacych swobodę ludzi. Chcieli tworzyć typ cztowieka niejako uniwersalnego: zwycięzcy nad natura i nad cywilizacja, nad beztadnym żywiotem i nad nadmierna mechanizacja, nad przesada nonsensu i nad ścistymi więzami logiki ${ }^{45}$. Podobne źródła buntu inspirowały indyjskich twórców (np. Gadźanan Madhaw Muktibodh ${ }^{46}$ w wierszu Bezsilni ${ }^{47}$ mówił: mój sprzeciw jest gorzki - i była w tym określeniu trzeźwa samo-

wzorców postaci niż portretowaniu bohaterów indywidualnych, a poezja stużyta bardziej prezentowaniu motywów i konceptów niż ekspresji indywidualnej wrażliwości. Dopiero wówczas, gdy tworzący w jezzyku hindi pisarz odkryt siebie jako indywidualność, uświadomit on sobie również i to, że jako twórca ma do czynienia z osoba ludzka - S.H. Vatsyayan, Hindi Literature, [w:] Contemporary Indian Literature. A Symposium. New Delhi 1957, s. 80 i 84.

Ajñeyā, Mukti, [w:] Tär Saptak, s. 238.

45 Cytuję za polskim futurystą Anatolem Sternem, który w pełni tę opinię akceptował. Por.: A. Stern, Poezja zbuntowana. Szkice i wspomnienia, Warszawa 1970, s. 94.

Gadźanan Madhaw Muktibodh (1917-1964) - poeta, eseista, publicysta. Autor dziewięciu książek: dwóch zbiorów wierszy, poematu, trzech zbiorów opowiadań i trzech książek eseistycznych. Trzy książki poetyckie oraz pisma krytyczne ukazały się drukiem już po śmierci poety. W 1985 r. w New Delhi opublikowano sześciotomowe Utwory zebrane Muktibodha. 
świadomość), którzy deklarowali swój sprzeciw wobec trudnej rzeczywistości. Czynili to zwykle poprzez poetyckie ukazanie relacji między beznadziejnością sytuacji rzeczywistej a oczekiwaniami bądź poprzez budowanie obrazów metaforycznych opartych na kontraście pomiędzy nędzą - będącą niejako synonimem losu „mas” - a dostatkiem, w jakim żyli uprzywilejowani (głównie z tytułu urodzenia) członkowie społeczeństwa.

Poeci hindi widzieli zatem rzeczywistość w antynomiach. Z jednej strony zły, niesprawiedliwy, niemoralny świat stosunków społecznych, z drugiej - ich marzenia, jako alternatywa:

Ja samotny,

Przede mna bezkresna droga

Bardzo stroma.

[...]

Idęprzez wiosenna noc krok po kroku

Bez namystu, bez ratunku.

(Nemićandr Dźain, Nieświadomie cicho $^{48}$ )

Ty, który po catych stu latach

Będziesz czytat moje wiersze,

Ty jesteśn nowym kwiatem mojej ziemi

[...]

Czy będziesz w stanie zrozumieć,

Że sto lat temu

Ci, którzy śpiewali pieśni o wyzwoleniu,

O wolnej duszy,

Marzyliz zamkniętymi oczami...

(Bharatbuszan Agrawal, Pytanie do nadchodzacych ${ }^{49}$ )

$Z$ czterech stron wrzaski

$Z$ czterech stron wszystkiego petno

$Z$ czterech stron śmierć

Ttumy i śmieci.

(Giridźakumar Mathur, Dwa brzegi świata ${ }^{50}$ )

Akcent przesuwali więc w stronę wartości duchowych, wewnętrznych. Przyczyny buntu widzieli nie tylko w sferze społeczno-politycznej, lecz także w sferze psychologicznej, filozoficznej. Niekiedy bunt obrazowali w sposób niezwykle osobisty czy wręcz przybierający postać duchowego ekshibicjonizmu, jak Muktibodh w zdaniu: moje ja jest brudne jak ptynący rynsztok, albo poszerzali pojęcie buntu o sens metaforyczno-

\footnotetext{
48 N. Jain, Anajāne cup cap, [w:] Tär Saptak, s. 64.

49 B. Agravāl, Āne vāloì se ek savāl, [w:] Tār Saptak, s. 100.

50

G. Māthur, Do pātọ̇ kì duniyā, [w:] Tār Saptak, s. 171.
} 
-metafizyczny, jak Dźain, który peten niespokojnej chciwości słyszał gtosy mieszkające $w$ molekutach powietrza, widział otwarte ciato rzeki w czyimś magicznym oku, wiedział, że ma śpiewać czarne, zbuntowane pieśni. W największym skrócie można zrekonstruować tematykę buntu w wierszach poetów antologii Tar Saptak w sposób symboliczny: jako drogę wiodącą od inspiracji społecznych do egzystencjalnego sensu. Dla Dźaina droga ta była „bezkresna”. Dla Agrawala u jej kresu była niepewność zawarta w pytaniu do potomnego, tego „nowego kwiatu ziemi”. Mathur widział po obu krańcach tej drogi „Śmierć, tłumy i śmieci”. Skala napięć emocjonalnych wewnątrz tych zmetaforyzowanych obrazów świadczyła o stanach umysłu, rozedrganej świadomości, aspektach psychologistycznych współtworzących tę metaforykę.

Sprzeciw wobec realiów codziennej egzystencji budził w poetach hindi pragnienie przemiany:

Ze wszystkich stron styszę tony melodii,

Wpadaja w moje uszy,

Stucham catym swoim ciatem,

Wszystkie zmysty sa uskrzydlone!

(Prabhakar Maćwe, Nadejście wiosny ${ }^{51}$ )

Wierz w to, co jest prawdziwe, trudne -

[...]

Ciato być może jest szczęśliwe, ale nie ma końca smutkowi umystu

(Giridźakumar Mathur, Nie dotykaj cienia ${ }^{52}$ )

Te dwie poetyckie manifestacje pozornie tylko odnoszą się do heterogenicznego świata zastanego - z różnych pozycji stanu ducha i w różnych tonacjach emocjonalnych. Maćwe, poprzez użycie czasowników „słyszę" i „słucham” - dopowiedzianego "całym ciałem” - referuje czytelnikowi swój fizykalny, intensywny związek z odgłosami świata, wyrażalnymi „tonami melodii”. Związek ten poeta wypowiada nader realistycznie - zmysłem słuchu absorbuje wrażenia dźwiękowe, działające na receptory ucha wewnętrznego i rozchodzące się po całym ludzkim wnętrzu (czyli: w świadomości). Te „tony” symbolizują wielość i różnorodność świata materialnego (a korespondują z „czterema stronami wrzasku” Mathura) i „uskrzydlają” wszystkie zmysły. W tych linijkach zawarł Maćwe poetycką próbę maksymalnego zbliżenia się do realności świata, poprzez synestezyjny związek zmysłowości i estetyki. Trochę inaczej jest w zdaniach Mathura. Są one wyraźnie kategoryczne i adresowane do odbiorcy. Pierwsze utożsamia prawdę z trudem i jest w nim filozoficzny kontekst, echo jakichś bliżej niesprecyzowanych praktyk ascetycznych. Drugie mówi o wewnętrznej sprzeczności doświadczenia, sprzeczności między zmysłami a umysłem. „Szczęście” ciała przeciwstawione zostało „smutkowi umystu”.

51 P. Mācve, Vasantāgam, [w:] Tār Saptak, s. 115.

52 G. Māthur, Chāyā mat chūnā, [w:] Tār Saptak, s. 183. 
U genezy takich obrazów leżał sprzeciw wobec wynaturzonych procesów cywilizacyjnych. Jest to pozornie tylko zaskakujące u poetów awangardowych, którzy przecież $\mathrm{w}$ różnych formach wielbili zdobycze techniki dwudziestowiecznej. Przyczynę tego paradoksu stanowi wszakże fakt, że wiara w ludzką istotę, profetyczne widzenie człowieka tzw. prostego, np. robotnika, musiała doprowadzić poetów do wniosku, iż sprawą artysty jest właśnie obrona przed niektórymi konsekwencjami cywilizacji umasowionej jednostek najmniej świadomych zachodzących zmian.

\section{ZAKOŃCZENIE}

W wybranych tekstach poddałam analizom zwłaszcza takie fragmenty wierszy, w których ujawniały się formy rozumowego pojmowania wolności, na poziomie intelektualnym podlegające procesowi retorycznej werbalizacji ${ }^{53}$.

Opisane formy pojmowania wolności można przełożyć na idee w sposób następujący: idea niepodległości, idea autonomii twórcy, idea awangardowości. Pierwsza zawierała w sobie: a) wolność polityczną, b) wolność ustrojową, c) tożsamość kulturową (tę ostatnią manifestowano m.in. w absolutyzowaniu patriotyzmu, pojmowanego jako wypadkowa dwóch składników: ziemia plus język). Druga obejmowała: a) wybór wartości języka hindi, b) eksperymentowanie z tym językiem, c) eksperymentowanie z własną wyobraźnią. Trzecią tworzyły: a) radykalizm sprzeciwu wobec tradycji, b) wartość wiersza zintelektualizowanego, c) pragnienie reformowania rzeczywistości.

Ideom tym odpowiadały kolejno: idei niepodległości - teksty tych autorów, których określiłam jako prekursorów poezji w khariboli hindi; idei autonomii - teksty poetów zaliczanych do ćhajawadu; idei awangardowości - teksty poetów nowatorów zaliczanych do wczesnej fazy nurtu nai kawita.

Klasyfikacje te niewątpliwie mają cechę autentyczności. Należy jednak w tym miejscu uczynić zastrzeżenie, że we wszystkich trzech okresach w twórczości poetów do nich zaliczanych istniały - choć początkowo tylko w postaci symptomów - elementy wspólne bądź synchroniczne z ideami europejskimi, a sama idea wolności osobistej (a także buntu, traktowanego jako pierwszy etap dążenia do tej wolności) ma w Indiach genezę, najogólniej mówiąc, „zachodnią”. Łączy się bowiem ściśle z pojęciem indywidualizmu twórcy (i jednostki w ogóle) i dotyczy zwłaszcza tych poetów, którzy siebie i swoją poezję włączyli w polityczną działalność lewicową, w tym także partyjną, komunistyczną. Ich złudzenia i porażka - przede wszystkim ideologiczna - z perspektywy historycznego dystansu wydają się podobnej proweniencji i skali jak doświadczenia poetów europejskich. Jedynie tam, gdzie indywidualny talent przewyższał ideologiczne dogmaty, poeci odnieśli zwycięstwo w tym sensie, że teksty - o ile miały wartość artystyczną - przetrwały i świadczą raczej o głębokiej wrażliwości i duchowości autorów

53 Warto w tym miejscu po raz kolejny przywołać słowa Raghuwira Sahaja, poety późniejszej fazy nurtu nai kawita, który stwierdził, że [...] wolność byta i być powinna procesem ciagtym. Twórczość to rezultat wolności lub dążenia do niej- R. Sahaj, Wolnośćpisarza..., s. 11. 
niż tylko o ich zabłąkaniu w historii politycznej. Bowiem talent wytwarzający artystyczną wartość zawsze jest efektem wolnej myśli i wolnej wyobraźni.

Pojęcie indywidualizmu zazwyczaj kojarzone jest z dwiema wartościami: autonomią wewnętrzną i poczuciem duchowej wolności. Ale w analizach tekstów musiałam szczególnie uwzględnić także i to, co Gerhard Oberhammer określił jako pojęciowo-światopogladowa refleksję indyjskiego kontekstu kulturowego ${ }^{54}$. Pojęcie indywidualizmu (ahamkara) w Indiach nie było tożsame z pojęciem wolności w znaczeniu europejskim. Wolność twórcza, tak jak ją rozumieli poeci ćhajawadu, była szokiem dla indyjskiej inteligencji, gdyż zrywała z tradycją nie tylko nowym stylem czy potocznym słownictwem, ale zrywała również z tą "pojęciowo-światopoglądową” tradycją religijno-filozoficzną, przenosząc do wewnętrznej autonomii poety całość percepcji świata zewnętrznego, bez oparcia tej percepcji na jakimkolwiek systemie. Z takiej postawy wynikło nie tylko semantyczne skomplikowanie ćhajawadowej poezji, ale przede wszystkim całkowita jej odrębność, w tym m.in. od dotychczasowej społecznej funkcji poezji. Nie inaczej było (w odbiorze społecznym) z poezją epoki nai kawita. I w takim - i tylko w takim - sensie pojęcie autonomicznej wolności oraz związanego z dążeniem do niej buntu odnosi się do wszystkich analiz przeprowadzonych dla celu tego artykułu. Wszelkie inne znaczenia terminu „wolność" w ówczesnej poezji hindi były jedynie literackimi postulatami, chociaż - zarówno w sposób estetyczny, jak i intelektualny - wyrażanymi niezwykle absorbująco.

\section{BIBLIOGRAFIA}

Atharwaweda. Hymny wybrane, przeł. H. Marlewicz, C. Galewicz, Kraków 1999.

Czekalska R., Rodowody nowoczesnej poezji hindi (od ćhajawadu do nai kawita), Kraków 2008.

Eliade M., Traktat o historii religii, przeł. J. Wiertusz-Kowalski, Łódź 1993, Plejada.

Frauwallner E., Historia filozofii indyjskiej, przel. L. Żylicz, t. 1-2, Warszawa 1990.

Gaeffke P., Hindi Literature in the Twentieth Century, Wiesbaden 1978.

Handa R.L., History of Hindi Language and Literature, Bombay 1978.

History of Indian Literature, red. J. Gonda, t. 8: Modern Indo-Aryan, cz. 1, fasc. 5.

Jindal K.B., A History of Hindi Literature, New Delhi 1993, History of Indian Literature, red.

J. Gonda, t. 8: Modern Indo-Aryan Literatures, cz. 1, fasc. 5.

Kavitā kà śuklpakș, red. B. Simhh, A. Pradhān, Nayī Dillī 2001.

Kowalska-Soni A., Wspótczesna poezja hindi a rodzima tradycja literacka, „Przegląd Orientalistyczny" 1968, nr 1 .

Kozielecki J., Transgresja i kultura, Warszawa 1997.

Lemert Ch., Gillian G., Michel Foucault. Teoria spoteczna i transgresja, przeł. D. Leszczyński, L. Rasiński, Warszawa-Wrocław 1999.

Lévinas E., Catość i nieskończoność. Esej o zewnętrzności, przeł. M. Kowalska, Warszawa 1998, Biblioteka Wspótczesnych Filozofów.

54 G. Oberhammer, Wstęp, [w:] E. Frauwallner, Historia filozofii indyjskiej, przeł. L. Żylicz, t. 1, Warszawa 1990, s. 12. 
Literary Cultures in History. Reconstructions from South Asia, red. S. Pollock, New Delhi 2004. Machve P., Modernity and Contemporary Indian Literature, New Delhi 1978.

Mahādevī Varmā. Saricayitā, red. N. Jain, Naȳi Dillī 2002.

Maithilīsaran Gupt. Saricayitā, red. N. Naval, Naī Dillī-Paṭnā 2002.

McGregor R.S., Hindi Literature from its Beginnings to the Nineteenth Century, Wiesbaden 1984, History of Indian Literature, 8.

Nirālā samicayitā, red. Ḍ. Rameścadr Śāh, Nayī Dillī 2001.

Pandey I.P., Hindi Literature, Trends and Traits, Calcutta 1975.

Rai A., Hindi Nationalism, New Delhi 2007, Tracts for the Times, 13.

Rilke R.M., Śpiew jest istnieniem, przeł. B. Antochewicz, Wrocław 1994.

Rutkowska T., Historical Elements in the Riti Poetry (On the Example of Bhušan's Works), [w:]

Proceedings of the Fourth International Conference on the Theoretical Problems of Asian and African Literatures, red. M. Gálik, Bratislava 1983.

Rutkowska T., Kanon a wartość dzieta literackiego ( $w$ obronie literatury riti), „Przegląd Orientalistyczny" 1979, nr 1.

Rutkowska T., Stasik D., Zarys historii literatury hindi, Warszawa 1992.

Sahaj R., Wolność pisarza i wolność państwa, przeł. B. Budzianowska, „Literatura na Świecie” 1980, nr 10.

Schomer K., Mahadevi Varma and the Chhayavad Age of Modern Hindi Poetry, Delhi 1998.

Stern A., Poezja zbuntowana. Szkice i wspomnienia, Warszawa 1970.

Tār Saptak, red. Ajñeyā, Nayī Dillī 1995.

Tucci G., Mandala, przeł. I. Kania, Kraków 2002.

Varma R.S., The Influence of English on Modern Hindi Poetry \& Criticism, Allahabad 1954.

Vatsyayan S.H., Hindi Literature, [w:] Contemporary Indian Literature. A Symposium, New Delhi 1957.

Walka romantyków z klasykami, wstęp i oprac. S. Kawyn, Wrocław 1960, Biblioteka Narodowa, I 183.

Dr hab. Renata CZEKALSKA - orientalistka; adiunkt w Instytucie Bliskiego i Dalekiego Wschodu UJ. Jej zainteresowania badawcze obejmują: dziedzictwo kulturowe, historię oraz współczesne zagadnienia polityczno-społeczne Azji Południowej, a także teorię i pragmatykę przekładu literackiego oraz jego funkcję w komunikacji międzykulturowej. Autorka m.in. Rodowodów nowoczesnej poezji hindi (2008) i Traktatu o sztuce celebracji (2009), a także kilku antologii przekładów poezji polskiej na język hindi oraz poezji indyjskiej na język polski. 